\title{
The Medium (Non-) Specific: Rope, Dogville, and Mukařovský's Space-as-Meaning
}

Nenad Jovanovic

For Veronika Ambros

\section{Theoretical considerations: Mukařovský, Eisenstein, Bazin}

First published in 1933, Mukařovský's "A Note on the Aesthetics of Film" (MUKǍ̌OVSKÝ 2016 [1933]) is a liminal text: it both reflects the then dominant theoretical positions, informed significantly by film's silent legacy, and anticipates the realist orientation in theorizing cinema that would supplant formalism's status of primacy following the global standardization of sound film.

Before I elucidate Mukařovskýs position vis-a-vis the two strains of thinking and the causality posited between the advent of sound and the theoretical shift, I want to define the terms "formalism" and "realism", both of which have come to connote an array of often irreconcilable meanings. The one that corresponds to the historically earlier theoretical approach, formalism, refers here to the Russian thinkers affiliated with the Moscow Linguistic Circle and the Society for the Study of Poetic Language in St. Petersburg. Even so, the figure most frequently invoked in relation to formalist film theory is not Eichenbaum, Tynjanov, Shklovsky or any other writer affiliated with one or the other group, but a practitioner and thinker who did not belong to either - Sergei Mikhailovich Eisenstein.

A fallacious reason for that concerns the accusations of formalism that Eisenstein faced in the Soviet Union following Stalin's ascension to power and the establishment of socialist realism as the only aesthetic model in line with the country's purportedly revolutionary goals. A justified reason for the widespread association of Eisenstein with the formalist tradition concerns the indebtedness of his practice and theory to central formalist concepts, of which I will provide two examples. The first is his use Roman Jakobson's concept of the dominant - the "focusing component of a work of art" that "rules, determines, and transforms the remaining components" (JAKOBSON 1978: 82). Much of Eisenstein's theorizing of film is animated by the trope of collision: juxtaposed shot elements and shots should be selected and arranged so as to maximize a sense of 
conflict between them. Recognizing that a full application of this principle inevitably leads to a complete formal disunity, Eisenstein adopted the concept to suggest the possibility of a hierarchy - and therefore ultimately harmony - among the contrasting and opposing elements of a film. Another, broader example of a commonality between the Formalists and Eisenstein is their shared interest in films as sign systems, exemplified by all writings of the former group I have accessed, and - in Eisenstein's case - perhaps most pointedly and concisely by his 1929 article "The Cinematic Principle and the Ideogram."

In both his aesthetic and political predilections, Eisenstein was eminently a product of modernity and modernism. Given that his work reflects many of the period's prominent cultural tendencies, it is curious that this author of the contemporarily most sustained arguments for the creative potentials of film does not apply to the medium the then intellectually fashionable notion of medium specificity. ${ }^{1}$ That notion - referring to the idea that every medium, and the corresponding art form, are better suited for some thematic and stylistic choices than for some other ones - is central to both Mukarrovskýs account of the medium, and for the corpus of texts that are today collectively referred to as realist film theory, with André Bazin as the most fertile and influential contributor. Bazin believed in cinema's ontologic difference from all other media and art forms, basing that belief on film's capacity to credibly reproduce the visible and audible reality with a minimal human involvement. Because many of the most distinctive film techniques concern editing - championed by Eisenstein in both his work as a theorist and practitioner - one might infer that he, too, was a proponent of medium specificity, which animated much of the contemporary discourses on the arts. In fact, his aesthetics are unabashedly derivative from other artistic disciplines, and highlight film's eclectic - or synthetic - potential.

The other term that needs defining is "realism" as Bazin understood it. Even though his essays on film include the unelaborated thought that "[o]n the other hand, of course, cinema is also a language" (BAZIN 1960: 9), the most characteristic expressions of his ideas can be productively regarded as antithetical to the semiotic concerns of the Russian formalists and the Prague school. Bazin's emergence as a thinker coincided with major developments in film technology that sought to diminish the difference between cinematic representation and the manner in which most humans perceive reality with naked senses: sound film, colour film, and 3-D film. Based partly on this tendency and partly on an ethical system rooted in catholicism, he articulated in a series of short writings the view of cinema as a medium destined to capture the readily perceptible, an act that - for him - possessed a mystical quality. To further illustrate this through a series of Bazin's own metaphors, photography is for him the fingerprint, the holy shroud, the death mask, and the veil of Veronica (ANDREW 2004: xvi). This implies a pseudoreverence for the pro-filmic event in its integral form, and wariness about editing as an aspect of film form commonly utilized to transform the universally geographic into

1 For lucid and authoritative discussions of the evolution of Eisenstein's thinking, see (AITKEN 2001: 4-26; ANDREW 2004). 
a uniquelly filmic spacetime. Oft-quoted is Bazin's own hypothetical example that illustrates this view: if the scene showing an unarmed man with a beast is to assert its truth claim (which in his system constitutes a cinematic representation's raison d'être), the scene should be realized in a single shot, without resorting to editing's potentially manipulative powers.

Mukařovskýs account of film is split between these two broad orientations. Its first part seeks to demarcate cinema from the arts posited as related to it. Mukařovský implies cinema's phenomenological uniqueness by justifying what he sees as instances of the medium's "overstepping its boundaries" (MUKAŘOVSKÝ 2016 [1933]: 273): if drama, narrative literature, painting and music - the arts he quotes as comparable with film - do not lose their identity by "[extending] into the territory of another art" (MUKAŘOVSKÝ 2016 [1933]: 273), neither will cinema. The near-contradiction between Mukařovskýs remark that film continues to have but a few distinct norms and conventions (MUKAŘOVSKÝ 2016 [1933]: 273) and a later statement that film has now "mastered its material" and emancipated itself from the antecedent arts that share its visual and narrative orientation announce the bifurcating argument of the article's second, longer part, where the medium specificity argument is furthered through a discussion of the distinctive ways in which cinema constructs space.

Mukařovský begins by noting that the earliest cinema employed the stage as a reference point for its modeling of space (MUKA ǨVVSKÝ 2016 [1933]: 274). Indeed, in the films of such practitioners as Georges Méliès, the camera offers a field of vision analogous to that obtained from a central seat in the conventional theatre house, its axis perpendicular to that of the (imaginary) wall at the playing space's farthest edge, and the height of the average human figure photographed from the position constituting approximately two thirds of the frame's height. Mukařovský then proceeds to delineate the manners in which this convention has changed with the medium's development, citing three devices through which film space can be created (the shot, the shot transition, the close-up and off-screen sound) (MUKAǨOVSKÝ 2016 [1933]: 276). All four of these elements and techniques are discussed in terms of how they emphasize the difference between cinema's representation of the pro-filmic event, and how that event would be perceived with naked sight and hearing in theatre: cinema typically alternates among various vantage points and distances from the object photographed, whereas the stage typically offers a fixed one.

In commenting on both visual and aural properties of cinema, Mukařovský stresses the editing principles of the globally prevalent "Hollywood"-style films. Those principles lend themselves to an interplay between revealing the spaces previously implied to exist in the narrative, and implying the existence of spaces within it that would be revealed only later. It is, then, a shot's lack - its "non-content" - that motivates and justifies its transition to next shot. As often as showing space directly, cinema implies it by providing apposite cues, which the viewer then cognitively synthesizes into an idea of a spatial totality.

Theatre, of course, possesses an analogous device of the off-stage space, but does not employ it as a constitutive structural element. Often, it seeks to distract the spectator 
from the parts of the storyworld not represented on the stage, a choice made possible by its operation on the principle of addition: elements denoting and connoting a forest, for instance, need to be brought into the venue in order for the setting for A Midsummer Night's Dream to be established as such. Regardless of whether that entails the visually minimalistic approach of a Peter Brook, or the baroquely rich style of a Max Reinhardt, those elements - in the hands of a theatre practitioner worth her salt - will perform significatory functions.

This is not quite so in lens-based cinema. Lacking an equivalent of the empty stage and being innately realist as a consequence, it operates on the principle of subtraction: the stylization of the pro-filmic event by the Lumière Brothers entailed deciding what to exclude from their frames (for example, everything but the train and the passengers at La Ciotat station, everything but the opening gates of their factory and the workers exiting it). But regardless of how closely the filmmaker might attempt to guide the viewer's visual perception of the pro-filmic event through cinematography, editing and sound, the shots will always include some information that is not compatible with their semiotic purposes. To use the example Mukařovský employs to argue otherwise, the shot description "their knives" from Louis Delluc's script Spanish Fiesta (MUKAŘOVSKÝ 2016 [1933]: 278) does conjure up a close-up shot of the objects, but their actual appearance in a moving photographic picture would contain additional information - concerning their age and place of origin, for example - which would necessarily and profoundly inform the viewer's meaning-making process. ${ }^{2}$

One might hypothesize that it was the unselective nature of the camera lens and the microphone that has inspired the development of the style alternatively called classical, "Hollywood", or invisible. With the broad function of securing the viewer's constant orientation in filmic spacetime, and of guiding her perception of narratively vital cues, the style counters the informational clutter that would otherwise result from cinema's capacity to register and reproduce the pro-filmic event in a manner that closely corresponds to its actual visual and aural parameters. David Bordwell, Janet Steiger and Kristin Thompson cite 1917 as the year when the style's development was brought to a completion (BORDWELL, STEIGER and THOMPSON 1985). Writing at the time when its adjustment to the technological circumstances of sound film was being finalized, Mukařovský places emphasis not on the style's capacity to forge an impression of spatio-temporal coherence, but on its ability to disrupt that impression to an effect that can be best qualified as estranging. For brevity, I will offer but three consecutive examples. One: writing about the ability of cinema to combine the horizontality of the frame with the vertical perspective of low-angle and high-angle shots, Mukarovský identifies an increase of spatial illusion as the technique's effect, but this refers to the plasticity of the space depicted within the frame, rather than the incremental sculpting of spatio-temporal relations among the pro-filmic events portrayed in different shots, as a primary aim of the classical style (MUKǍ̌OVSKÝ 2016 [1933]: 275). Example two: he illustrates the observation that the "illusionistc displacement" can result from 
a film's change of angles and lenses from shot to shot with the example of a film that defies the laws of physics and physiology by "throwing" the spectator alternately under the wheels of a racing car, at its speedometer, and at its steering wheel (MUKAǨOVSKÝ 2016 [1933]: 275). Example three: his discussion of how editing can be used to elicit suspense includes close-ups of a weapon that two wrestling opponents are trying to reach (MUKǍ̌OVSKÝ 2016 [1933]: 276). But the fact that Mukařovský does not configure the shots as either character's vision of the weapon draws the viewer's attention to editing - an outcome that classical style seeks to avoid.

It appears that, for Mukařovský, replicating the spatial relations among objects as we perceive them without cinema's mediation is contrary to art's mandate. The idea that an artistic representation of an object should possess qualities substantially different from that object's qualities as it would be perceived in the extra-artistic context is key for both Russian Formalism and Czech Structuralism. Different writers express it with distinct but interrelated terms estrangement (ostranenie), de-automatization, and foregrounding (aktualizace). This view conforms closely to Eisenstein in his constructivist phase, and a range of other early theorists and practitioners who advocated the medium's use of its unique devices as a way of legitimizing itself as an art. But the very suggestion that film's failure to do so will result in a faithful and therefore neutral reproduction of optical and aural phenomena as they appear to us in the extra-artistic context carries a connotation that would later come to be associated with Bazin, minus the mystical dimension he ascribed to it.

That Mukařovský sees cinematic semiosis as intrinsically tied to theatre and narration can best be gleaned from his discussion of Vertov's Man With a Movie Camera (MUKǍ̌OVSKÝ 2016 [1933]: 280-281). Towards the end of the essay, he approvingly evaluates the film as an example of how prioritizing space over narrative is not only possible, but enhances the medium's "specific” character (MUKAŘOVSKÝ 2016 [1933]: 282). Yet his longer discussion of the film nearly dismisses it as an exception nearly devoid of a theme, and assessment in line with Eisenstein's description of Man as an example of cinematic hooliganism (PETRIC 1987: 17). The film, however, does have a few interrelated themes beyond "a day in the city streets" - the obvious one identified by Mukařovský (2016 [1933]: 281) - of which the relationship between cinema and theatre is relevant to my topic. Man associates film with the socialist present, and theatre with the bourgeois / feudal past in multiple instances, most vividly through the image of an imploding Bolshoi theatre, produced - significantly - through the medium-specific techniques of double exposition and canting camera. It is hard not to hypothesize that the reason for Mukařovsky's failure to acknowledge the film's anti-theatrical stance concerns his view that non-conventional films "[suppress] sequential space in favour of the action" (MUKAŘOVSKÝ 2016 [1933]: 282) and that "the more weakly the plot is connected through motivation [...], the more easily the dynamics of space can be brought to bear in plot” (MUKAǨOVSKÝ 2016 [1933]: 282). These words read as an inversion of the Aristotelian tenet on the correlation between the unities of dramatic action and of spacetime, indicating its continued relevance and applicability to film. First questionably proclaiming Man to have no theme, and then - incontestably - to 
have no narrative, Mukařovský implies that a film cannot mean if it does not narrate, a proposition that Man seeks to dispel.

This pro-classicist bias can only be reconciled with Mukařovskýs view that "[t]he history of art has much more the nature of a perpetual revolt against the norm" (MUKǍ̌OVSKÝ 1978: 54) if the historical moment is considered in which "A Note on the Aesthetics of Film" was written. In the early 1930s, the globally influential Soviet montage-based filmmaking was replaced by a party decree with the aesthetics of socialist realism, predicated stylistically on the formal procedures of "Hollywood." A similar development took place in Nazi Germany after Joseph Goebbels, a fan of Eisenstein's Battleship Potemkin (1925), had recognized the greater efficacy of the American style of cinematic storytelling in promulgating ideological messages.

The respective stylistic shifts were not brought about solely by politics, however. A technological factor limited the applicability of rapid editing characteristic of montage-based films: the advent of sound, an occurrence that André Bazin would later employ to support his view of the medium's development as informed by the need to diminish the gap separating our perceptions of the real without and with the mediation of film technology. One example must suffice of the great perceptual difference between a silent film image, and a film image accompanied by synchronous sound. A trained eye can read a single frame (the duration of which is a small fraction of a second), but the equally short segments of sounds become indistinguishable from each other. Sound film lends itself to shots of greater duration and the average shot length doubled as a result of the transition to talkies (SALT 1983: 231-232). That fact, along with the simultaneous commercial development of a range of devices that facilitated camera mobility, paved the way for the long-take film aesthetic that in the 1940 s dominated both America and Europe. Bazin saw avoidance of editing as a pathway to cinematic realism, which for him crucially differed from realisms in other arts on account of film's photo-chemical and mechanical nature. His view that cinema reproduces space and time rather than depicting it was previously anticipated in Mukařovskýs "Notes."

Ever since the articulations of this view, filmmakers with an experimental slant have been creatively utilizing the similarities and differences between geographic and cinematic spacetime to produce what Mukařovský terms space-as-meaning. Cases in point are Alfred Hitchcock's Rope (1948) and Lars von Trier's Dogville (2003), a classical "Hollywood" film and a European art film, which demonstrate that the convergences and divergences between the two kinds of space are often emphasized through diverse references to theatre.

\section{Practical considerations: Mukařovský, Hitchcock, von Trier}

Before delving into the apparent differences and hidden similarities in their respective construction of filmic space, I want to point out that the films lend themselves to a comparison also at the level of narrative: both explore the distinction between civic and alternative, "higher" value systems. Rope focuses on two students who strangle a third in 
the name of a perceived intellectual superiority over their victim and other people. To validate that stance, the students commit the crime at the setting for, and immediately prior to the beginning of, a party whose guests comprise the murdered man's relatives and friends, and use sophistic arguments to dispel the mounting suspicion of his and his killers' former teacher that the crime has been committed, and that its perpetrators are the party's hosts. Dogville is a story about a beautiful and mysterious fugitive woman finding shelter from her pursuers in the remote mountain town, whose inhabitants' attitude toward her devolve over the course of the narrative from compassionate to utiliatarian and from utlitarian to sadistic. Like Rope, Dogville ends with a philosophical dialogue on the merits and demerits of two broadly contrasting ethical systems as they relate to the entitlement of one human being to take another's life.

As can be inferred from the brief summary of Rope I have given, the film conforms to the classical unities, reflecting the narrative's lineage as a stage play by Patrick Hamilton (1929). It opens with an inciting incident (the murder) and ends as soon as a denouément is reached (the resolution of the murder case), with the characters entering and exiting in the order of their dramatic importance. Yet the link Rope establishes between its formal procedures and its thematic preoccupations saves it from the pitfalls of "filmed theatre." As Gorge Toles notes, "Rope is a theatrical movie in which theatricality is what people need to be saved from, without there being any way out of it. The human connections that continue to be active and urgent in the film (whether through efforts to pull away or to overcome separateness) mostly have to do with reinforcements of self-as-theater" (TOLES 2001: 217).

Rope was produced at the time when Bazin was formulating his understanding of cinematic realism, inspired by the aesthetic tendencies that were marking the postWorld War Two years in Europe and the United States alike. Italian neorealism - with its stress on the fortuity of everyday occurences, and its favouring of mise-en-scène over editing - was at its pinnacle. The same combination of narrative and stylistic tendencies could be evidenced also in Hollywood, exemplified by such films as William Wyler's The Best Years of Our Lives (1946). In the hands of a Wyler or a Rossellini - the latter filmmaker being a pioneer of Italian neorealism and its preeminent representative - the long take functions as a platform suited for capturing the contingencies of everyday life. Much as Vertov's camera trickery in Man corroborates the idea of the advantages of the novel medium of film over the ancient medium of theatre - which an image of an actually collapsing Bolshoi Theatre would merely and vaguely hint at - the long take operates in many of the period's films as a tacit guarantee of the authenticity of the represented storyworld. The perceptual logic invited by the long take is as follows: if the film is refraining from the use of the supremely cinematic techniques of editing and the close-up, it must be doing so in order to be able to capture events that can always occur unplanned. Thus the prolonged duration of the long take in neorealist and other films of the period that opposed the classical dramatic structure often functions as a synecdoche for geographic time, whereas the predilection of these traditions for greater camera distances operates as a synecdoche for geographic space. 
With a characteristic slyness, Hitchock embraces the long-take aesthetic of many of the period's films, but turns it against itself. In Robin Wood's characteristically brilliant analysis;

One can define [Rope] by saying that [it] is the film that most strikingly justifies the antipathy to Hitchcock's work evident in the writings of that most eloquent exponent and theorist of the

long take, André Bazin. [...] For Bazin, the long take, absence of editing, and use of depth of field played a key role in the cinema's potential objectively to "reveal" reality [...], and to realize itself as the ideal "democratic" art: the spectator is left free to choose which aspect of the image he will concentrate on, his response no longer dictated by the manipulation of Eisensteinian (or Hitchcockian) montage. For Hitchcock, the experimentation of Rope is never in the least conceived as in opposition to his already highly developed montage technique [.] (WOOD 2002: 350)

Rope features only nine cuts within the 80 minutes of its runtime. Five of those cuts conceal themselves as such through various interactions of figure and camera movement, whereby the screen darkens completely at the transitional moments, rendering indiscernible the majority of splices that connect the film's several long takes. The other cuts are not disguised for technical reasons: occurring roughly at the end of every other, ten-minutes long film reel, they are intended to help the projectionist cue the beginning of every odd-numbered reel.

By forgoing editing, the film assigns the construction of space entirely to figure movement in interaction with camerawork. Even the compositionally relatively simple first long take features shot scales ranging from medium-long to close-up, and employs mobile framing to take us through four distinct spaces of the New York penthouse where the narrative is set. Both the play and the film organize their respective narratives around the taboo sight of the corpse lying in a chest center stage, that is in the room of the apartment where the bulk of the action takes place. But the camera's mobility has meta-narrative implications, too. In a production of the play in an architecturally conventional venue, the visual limits marked by the corpse would be echoed by those of the entrances and exits to and from the playing space. The film, in contrast, creates a distinctly "stagey" feel only initially, by showing the two characters from a single vantage point for four and a half minutes, and by restricting the camera movements to a few axial and inconspicuous ones. Once it has established the boundaries of the camera's reach, however, the film transgresses them, seemingly for a reason analogous to that for the protagonists' murder of their colleague: to demonstrate its superiority over theatre, which the film uses as a point of comparison with its own chosen medium.

Hitchcock famously quipped that cinema should be a piece of cake rather than a slice of life (TRUFFAUT 1984: 103). In light of that poetic mandate, it is unsurprising that the mentioned remolding of geographic space - and the breakage of the narrative illusion as its consequence - serves a non-naturalistic function. Besides helping convey the passage of time, the exterior vista observable through the windows of the room where the chest is located features a neon sign representing the filmmaker's cartoonish profile - a pseudo-cameo that aligns Rope with a long series of Hitchcock's films starting with The Lodger (1927). 
In addition to this reflexive element, Rope's urban night contains a purely expressive one: the red-green blinking of an off-screen neon sign, reminiscent of the police emergency lights, which becomes prominent when the metaphorical noose begins to tighten around the crime's perpetrators. The anti-naturalistic effect is compounded by the theatrical acting and its interaction with the camerawork. But whereas John Dall's histrionic exaggerations - augmented by the portrayal's large scale - might threaten the storyworld's credibility by the inadvertent emphasis they place on the actor's staginess, they also allow to be seen as another of the film's various reflexive elements that assert the capacities of film style. Concretely, the proximity of the camera to the performer becomes a testimony to the ability of the close-up - and therefore of the medium of film - to accomplish something that the stage cannot: reduce the "setting" to a single performer's face.

While exaggerated, the continuity in Rope between the various spaces and sections of it, achieved through the film's reliance on the long take, remains incomplete. D. A. Miller's extremely thorough analysis delineates the numerous details betraying that Rope, whose story and plot time are almost equal, was photographed over the course of a period much longer than the film's runtime. Examples include a candle strengthened by an invisible hand off-screen, the melting of a sundae at an unnatural speed, and - most famously - by the healing of the wounded hand of Phillip Morgan (Farley Granger) within a couple of minutes of story time. As Hitchcock is a mainstream filmmaker even in Rope, his most experimental film, it seems safe to assume that the complex pattern of continuity errors in the otherwise meticulously orchestrated Rope was not part of the filmmaker's design. But signs have the habit of establishing themselves as such despite their creator's intention. In light of the film's other reflexive elements, it is difficult not to see the coexistence of the film's continuity and non-continuity as a deliberate attempt to at once emulate the manner in which phenomena appear to our eyes and ears, and to challenge that perception.

That Dogville at once highlights and challenges the differences between geographic, theatrical, and filmic space is more readily apparent. Von Trier has stated that his design of the setting was based on a vision of an impossible stage - a space whose entirety cannot be perceived from a single vantage point, and requires the aid of cinematography and editing to be presented to the viewer fully. As von Trier explains in an interview, "I decided that it shouldn't look like we were filming a theatre stage but that the whole thing should be stylized to such an extent that it couldn't take place in a theatre, although it should still have a sense of theatre to it" (BJÖRKMAN 2003: 246). With a story spanning a long period of time, and employing for its setting not a singular locale, but a multitude thereof - delimited by the boundaries of the titular American town - Dogville opposes the Aristotelian unities. Concomitantly, the film focuses not on a "special" individual, but on "ordinary" men and women populating the town, which synecdochally represents the entire country. This combination of formal traits have earned the film comparisons with Brecht's theatre, to which the film obliquely but repeatedly alludes. ${ }^{3}$ It is not, however, the film's intertextuality, but

3 For recent commentaries on Dogville's relationship to Brecht, see (KOUTSOURAKIS 2013: 143-186; LUEBECKER 2015: 21-26; JOVANOVIC 2017: 187-199). 
its intermediality that I am concerned with here: Dogville as perceived in the context of cinema, whose typically photographic nature confers it a realist mandate, does not equal Dogville as it would be perceived on stage. In theatre, the stage would pass unnoticed because the spectator would recognize it as integral to the architecture of the playing house, whereas on the screen it operates as an agent of stylistic unity that attenuates the film's anti-Aristotelianism. The film's locale is not simply the town, but also the impossible stage, whose extraordinary large size would not allow it to be visually absorbed from a single vantage point. Like Rope, Dogville uses the peculiarities of the performance space structure as an occasion for a display of cinema's ability to provide perspectives unattainable to both the conventional stage and the vision unmediated by the cinematographic apparatus.

Von Trier, whose early films show a high degree of directorial control in all aspects of film image and sound, began to combine in the mid-1990s a meticulous and a (pseudo-) careless audio-visual style. Central to the latter is a handheld, freely panning and zooming-camera, which has rendered much of the filmmaker's later style reminiscent of observational documentaries in the vein of the Maysles Brothers and P. A. Pennebaker, and a disregard of the 180 degree rule, foundational for organizing film space in the cinema of Hollywood and similar industries. Dictating that all camera angles utilized within a scene should be taken from the same side of the imaginary line connecting two centres of interest, the rule is intended to ensure consistency from shot to shot of eyelines and screen direction. Whereas von Trier's inattention to the rule in such films as The Idiots (1998) does not affect our understanding of the narrative, his camera's unpredictable and instantaneous shifts across the imaginary line in Dogville becomes a testimony to the artist's demiurgic powers, his ability to transcend physical boundaries.

This interpretation endows with a different meaning also the film's craning shots that frame the biggest, fictional part of the film. The first of those initially shows an aerial view of the town, whose painted streets and their inscribed names in combination with the camera angle employed render it map-like. Its descent onto the town's "soil" marks a symbolic abolishment of the initially posited difference between the sign (the map) and its referent (the "actual" Dogville), between the representation within a representation (the map in the film Dogville) and the "presentation" of Dogville the town. The other craning shot reverses the direction of the camera movement, as well as that of the transformation of the signs that constitute the shot's content. Initially, it shows Moses, the town's guardian dog, represented as a drawing in the white of the town's contours and street names. Through a dissolve, an actual dog materializes, barking directly at the lens in a medium close-up - an instance of cinematic version of the crossing of the Antoinian fourth wall achieved through a combination of medium-specific means. The biblical dimension of the aerial perspective - which practitioners and commentators alike often refer to as God's eye-view, irrespective of the context in which the device appears - is corroborated through the reference to the prophet.

Considered alongside the film's handheld shots, the craning ones - commonly associated with slick "Hollywood" studio filmmaking - invite the question of who, actually, 
is the film's God: the Supreme Being and the principal object of faith, or the filmmaker. In The Boss of it All (2006), von Trier's pseudo-Hitchcockian penchant for selfreferencing manifests itself in the filmmaker's on-screen appearances. Brief fictional sequences that follow major narrative turns show him with headphones and a video camera - "the boss of it all" commenting on the film as a one-man chorus that bears traces of both the Aristotelian and Brechtian representational traditions. But already in Dogville, the perspective we are provided with is quite literally von Trier's: he served as the film's camera operator, and the pans, tilts, zooms and small involuntary movements that handheld camera unavoidably causes are records of how the filmmaker saw the scenes as they were transpiring. This, too, is a way for a filmmaker to acquire a bodily presence within their work, comparable to Hitchcock's appearance in Rope and the majority of his other films.

\section{Conclusion: space-as-meaning, medium specificity, foregrounding}

While exemplary, Rope and Dogville are far from being rare instances of films that create Mukařovskian space-as-meaning through foregrounding the difference between the geographic and filmic space and time. Take, for instance, the early film of the "Brighton school," The Big Swallow (James Williamson, 1902), where a man approaches the camera in a state of apparently growing agitation, covers its lens with a gaping mouth, and "spits out" the film's cinematographer in the next shot. The film's turn involves a conflation of space-time as photographed and spacetime as created through editing, which is to say a playful combination of the non-medium-specific (geographic) and medium-specific (cinematic). As a more recent example of an emphasized use of space in film, consider Roman Polanski's Knife in the Water (1962), which at once adheres to and violates the corresponding Aristotelian tenet. Most of the narrative is set on a small, but moving boat, and major narrative turns result from the characters' interactions with their immediate, fixed surroundings, and the broader, constantly changing ones. Finally, the even newer Synecdoche, New York (Charlie Kaufmann, 2008). It follows a director whose attempt to create a realistic stage representation of his work on an autobiographical play leads to the creation of a seemingly interminable theatre production with an infinite number of meta-levels. That is space-as-meaning. And given the effectiveness of transposing the formal conventions of theatre to film for the creation of the Mukařovskian concept this essay has been discussing, it is unsurprising that stage practitioners have often employed an equivalent strategy. Robert Lepage, for instance, deconstructs both cinematic and theatrical space by having the actors in his Lipsynch (2009) arrange disparate objects in deep space in a fashion that the live feed camera "sees" as a human smoking a cigarette.

A final point requires a return to the essay that inspired this commentary. If Mukařovský has difficulties squaring the view that film's need to exist independently from theatre and other antecedent art forms with his recognition of film's continued rootedness in those art forms, that is so because the above proposition is not an either 
/ or one, as the above examples hopefully suggest. I have tried to demonstrate that film often asserts its medium specificity precisely by adopting elements characteristic of other media. Mukařovský's "A Note on the Aesthetics of Film” implies this insight, which complements and corroborates his main one, that to transform geographic space into filmic one creatively is to foreground it.

\section{Bibliography}

AITKEN, Ian. 2001. European film theory and cinema: a critical Introduction. Edinburgh: Edinburgh University Press, 2001.

ANDREW, J. Dudley. 2004. Foreword to the 2004 Edition. In André Bazin. What Is Cinema? Berkeley: University of California Press, 2004: ix-xxiv.

ANDREW, J. Dudley. 1976. Sergei Eisenstein. In J. Dudley Andrew. The Major Film Theories: An Introduction, Oxford: Oxford University Press, 1976: 42-75.

Battleship Potemkin [film]. 1925. Directed by Sergei Eisenstein, performances by Aleksandr Antonov and Vladimir Barksy. Goskino, 1925.

BAZIN, André. 1960. The Ontology of the Photographic Image. Film Quarterly 13 (1960): 4: 4-9.

The Best Years of Our Lives [film]. 1946. Directed by William Wyler, performances by Myrnay Loy and Fredrich March. The Samuel Goldwyn Company, 1946.

The Big Swallow [film]. 1902. Directed by James Williamson, performance by Sam Dalton. Williamson Kinematograph Company, 1902.

BJÖRKMAN, Stig (ed.). 2003. Trier on von Trier. London: Faber and Faber, 2003.

BORDWELL, David, Janet STAIGER and Kristin THOMPSON. 1985. The classical Hollywood cinema: film style Eं mode of production to 1960. New York: Columbia University Press, 1985.

The Boss of It All [film]. 2006. Directed by Lars von Trier, performances by Jens Albinus and Peter Gantzler. Zentropa Entertainments, 2006.

Dogville [film]. 2003. Directed by Lars von Trier, performances by Nicole Kidman and Paul Bettany. Zentropa Entertainments, 2003.

ELBESHLAWY, Ahmed. 2016. Woman in Lars von Trier's Cinema. Cham: Palgrave Macmillan, 2016.

EISENSTEIN, Sergei. 1949. The Cinematic Principle and the Ideogram. Film Form: Essays in Film Theory. New York: Harvourt Brace, 1949: 28-44.

GUNNING, Tom. 2004. What's the Point of an Index? Or, Faking Photographs. Nordicom Review 25 (2004): 1-2: 39-49.

HAMILTON, Patrick. 1968. Rope: a play. London: Constable, 1968.

The Idiots [film]. 1998. Directed by Lars von Trier, performances by Bodil Jørgensen and Jens Albinus. Zentropa Entertainments, 1998.

JAKOBSON, Roman. 1978. The Dominant. In Ladislav Matejka and Krystyna Pomorska (eds.). Readings in Russian poetics: formalist and structuralist views. Ann Arbor: Michigan Slavic Publications, 1978: 82-87.

JOVANOVIC, Nenad. 2017. Brechtian cinemas: montage and theatricality in Jean-Marie Straub and Danièle Huillet, Peter Watkins and Lars von Trier. Albany: SUNY Press, 2017.

KOUTSOURAKIS, Angelos. 2013. Politics as form in Lars von Trier. New York: Bloomsbury Academic, 2013. 
The lodger: a story of the London fog [film]. 1927. Directed by Alfred Hitchcock, performances by June Tripp and Ivor Novello. Gainsborough Pictures, 1927.

LUEBECKER, Nikolaj. 2015. Feel-bad film. Edinburgh: Edinburgh University Press, 2015.

Man With a Movie Camera [film]. 1929. Directed by Dziga Vertov. VUFKU, 1929.

MUKAŘOVSKÝ, Jan. 2016 [1933]. A note on the aesthetics of film. In David Drozd, Tomáš Kačer and Don Sparling (eds.). Theatre theory reader: Prague School writers. Prague: Karolinum Press, 2016: 272-283.

MUKǍ̌OVSKÝ, Jan. 1978. The aesthetic norm. Structure, Sign and Function: Selected Essays by Jan Mukařouský, New Haven/London: Yale University Press, 1978: 49-56.

PETRIC, Vlada. 1987. Constructivism in film: the man with the movie camera, a cinematic analysis. Cambridge: Cambridge University Press, 1987.

Knife in the water [film]. 1963. Directed by Roman Polanski, performances by Leon Niemczyk and Jolanta Umecka. Zespol Filmowy “Kamera”, 1963.

Rope [film]. 1948. Directed by Alfred Hitchcock, performances by John Dall and Farley Granger. Warner Bros, 1948.

SALT, Barry. 1983. Film style and technology. London: Starword, 1983.

Synecdoche, New York [film]. 2008. Directed by Charlie Kaufman, performances by Philip Seymour Hoffman and Catherine Keener, Sidney Kimmel Entertainment, 2008.

TOLES, George. 2001. A house made of light: essays on the art of film. Detroit: Wayne State University Press, 2001.

TRUFFAUT, François. 1984. Hitchcock. New York: Simon and Schuster, 1984.

WOOD, Robin. 2002. Hitchcock's films revisited: revised edition. New York: Columbia University Press, 2002. 